\title{
DETECTION OF SECONDARY METABOLITE OF MYCENA PELIANTHINA GROWTH IN VARIOUS LIQUID MEDIUM
}

Nadya Denris Talitha Syarifah ${ }^{1}$

Nuraeni Ekowati ${ }^{1}$

Aris Mumpuni ${ }^{1}$

Iwan Saskiawan ${ }^{2 *}$
${ }^{1}$ Faculty of Biology, Jenderal Soedirman University, Purwokerto 53122, Indonesia

${ }^{2}$ Microbiology Division, Research Center for Biology, Indonesian Institute of Sciences-LIPI,

Jalan Raya Jakarta-Bogor Km 46, Cibinong 16911

\section{ABSTRACT}

Mushrooms which is mostly belong to the phylum Basidiomycota have been recognized as functional foods and a source for the nutraceuticals. Genus Mycena is one of mushrooms, which has been investigated for its secondary metabolites. Mycena pelianthina produces pelianthinarubins A, pelianthinarubins B, muscarin, and epimuscarin from alkaloid group. The purposes of this research were to determine the effects of composition of medium and incubation time on production of mycelial biomass of $M$. pelianthina in liquid medium and to know the group of secondary metabolite compounds produced. This research was done experimentally using a Factorial Completely Randomized Design consisted of 12 treatments and three replications. The first factor was medium type, which were Mushroom Complete Medium (MCM), Potato Dextrose Yeast Broth (PDYB), and Yeast Malt Extract Medium (YM). The second factor was the incubation time consisting of $15,20,25$, and 30 days. The observed main parameters were the dry weight of mycelial biomass and the secondary metabolite groups. The dried weights of mycelia were analyzed using analysis of variance (ANOVA), continued with Duncan test at a 95\% confidence level. The best growth of $M$. pelianthina mycelium was produced on PDYB medium at incubation time of 20 days with an average mycelial dry weight of $0.92 \mathrm{~g} / 100 \mathrm{~mL}$. M. pelianthina contained secondary metabolite compound groups of alkaloids, terpenoids, and flavonoids.

Keywords: Alkaloid, flavonoids, liquid medium, mycena pelianthina, secondary metabolite, terpenoids

\begin{abstract}
ABSTRAK
Jamur pangan merupakan salah satu bahan pangan yang dikenal sebagai pangan fungsional dan sebagai sumber nutrasetikal. Salah satu jamur pangan yang dikenal menghasilkan senyawa aktif sebagai metabolit sekunder adalah jamur Mycena pelianthina. Jamur ini dikenal menghasilkan senyawa metabolit sekunder pelianthinarubins A, pelianthinarubins B, muscarin, and epimuscarin dari kelompok alkaloid. Tujuan penelitian ini adalah untuk mengetahui pengaruh medium pertumbuhan dan waktu inkubasi terhadap bobot miselia $M$. pelianthina serta mengetahui golongan senyawa metabolit sekunder yang dihasilkannya. Penelitian ini dilakukan secara eksperimental menggunakan Rancangan Acak Lengkap Faktorial, dengan 12 perlakuan dan tiga kali ulangan. Faktor pertama meliputi jenis medium, yaitu Mushroom Complete Medium (MCM), Potato Dextrose Yeast Broth (PDYB), dan Yeast Malt Extract Medium (YM). Faktor kedua meliputi waktu inkubasi, yaitu 15, 20, 25, dan 30 hari. Bobot kering miselia tertinggi $(0,92 \mathrm{~g} / 100$ $\mathrm{mL}$ ) dihasilkan pada medium PDYB dengan waktu inkubasi 20 hari. $M$. pelianthina mengandung senyawa metabolit sekunder golongan alkaloid, terpenoid, dan flavonoid.
\end{abstract}

Kata kunci: Alkaloid, flavonoid, medium cair, metabolit sekunder, mycena pelianthina, terpenoid
Article Information

Article Type: Research Article

Journal Type: Open Access

Volume: 2 Issue 2

Manuscript ID

v2n2528-1

Received Date

15 December 2020

Accepted Date

4 February 2021

Published Date

17 February 2021

DOI: $10.33555 /$ jffn.v2i2.57

Corresponding author: Iwan Saskiawan

Cibinong, Indonesia, 16911

Email:

iwansaskiawan@gmail.com

Citation:

Syarifah, N.D.T., Ekowati, N., Mumpuni, A., Saskiawan, I. 2021. Detection of secondary metabolite of Mycena pelianthina growth in various liquid medium. J. Functional Food \& Nutraceutical, 2(2), pp.89-97

Copyright: $\odot 2021$ Swiss German University. This is an open-access article distributed under the terms of the Creative Commons Attribution 4.0 International License, which permits unrestricted use, distribution and reproduction in any medium, provided the original author and source are credited. 


\section{INTRODUCTION}

The potential of mushrooms as a functional food and as a source of nutraceutical has been widely studied and developed in several countries. Mushrooms are considered to produce various types of bioactive metabolites. These bioactive metabolites can be either primary metabolites or secondary metabolites (Ekowati et al., 2016). Various kinds of bioactive compounds have been isolated and identified, including those from the groups of polysaccharides, proteins, phenols, vitamin B, tocopherols, organic acids and terpenoids (Khatua et al., 2013). Some of them have been approved for clinical uses (Ren et al., 2014).

Mycena is a large group of Basidiomycetes. Several species belong to this genus have been studied for their bioactivity and the structures of metabolite compounds have been identified. Strobilurin bioactive compounds isolated from $M$. galopoda, M. atromarginata, M. rosella and $M$. vitilis have antifungal and antibacterial activity (Bäurle \& Anke, 1980). Leaianafulvene isolated from $M$. leaiana and tintinnadiol from $M$. tintinnabulum is cytotoxic (Engler et al., 1998). However, research on bioactive compounds produced by $M$. pelianthina has not been widely carried out.

Mushroom growth can be influenced by the composition of medium and incubation time. Liquid medium is widely used for production of mycelial biomass since it has advantages such as a short incubation period, low possibility of contamination, and easy to take of mycelia for further analysis (Ekowati et al., 2011). The composition of the medium can affect microorganisms for producing secondary metabolites. According to Suciatmih (2010), potato dextrose yeast broth is a fermentation medium commonly used for testing secondary metabolites. According to Behera and Gupta (2015), production of mycelial biomass in mushroom complete medium is higher than that of yeast malt extract medium. Mushroom complete medium is a complete medium that is very suitable for mushroom growth because it contains a source of carbon, nitrogen, vitamins, and minerals (Kim et al., 2002).

Mushrooms need time to hydrolyze available nutrient sources for growth and secondary metabolite production. The longer incubation time, the mycelium growth increases to a certain extent so that the production of metabolites is also high (Saputra, 2010). Bäurle et al. (1982) reported that the best growth of $M$. viridimarginata mycelium is at 25 days incubation on YMG medium.

Secondary metabolite compounds can be detected using TLC (Thin Layer Chromatography). It can separate chemical components, based on the principle of adsorption and partitioning of compounds by the stationary phase (adsorbent) and the mobile phase (eluent). The chemical compounds move up based on the mobile phase because the adsorption of adsorbent is different so that the chemical components can move at different distances based on the level of polarity. The displacement process causes the separation of chemical components (Alen et al., 2017). The purpose of this study were to elucidate the best media for production of mycelial biomass of $M$. pelianthina and to identify the compound group of secondary metabolites they produced.

\section{MATERIALS AND METHOD}

Pure culture of $M$. pelianthina was obtained from the Laboratory of Mycology and Phytopathology, Faculty of Biology, Jenderal Soedirman University. It was cultured on PDA medium on areas of $90 \mathrm{~mm}$ petri dish diameter. A piece of mycelium of $5 \mathrm{~mm}$ in diameter was inoculated using a cork borer in that various liquid media. The experimental design used in this research was a Factorial Completely Randomized Design (CRD) consisting of 12 treatments and three replications. The first factor was medium type i.e. Mushroom Complete Medium (MCM), Potato Dextrose Yeast Broth (PDYB), and Yeast Malt Extract Medium (YM). The second factor was the incubation time, namely, $15,20,25$, and 30 days. The main observed parameters were the dry weight of mycelia and the secondary metabolite groups. 


\section{The composition of liquid medium.}

The MCM was comprised of $20 \mathrm{~g}$ of glucose, 0.46 $\mathrm{g}$ of $\mathrm{KH}_{2} \mathrm{PO}_{4}, 1 \mathrm{~g}$ of $\mathrm{K}_{2} \mathrm{HPO}_{4}, 0.5 \mathrm{~g}$ of $\mathrm{MgSO}_{4} .7 \mathrm{H}_{2} \mathrm{O}, 2$ of $\mathrm{g}$ peptone, and $2 \mathrm{~g}$ of yeast extract (Kim et al., 2002). The PDYB was comprised of $200 \mathrm{~g}$ of potato, $3 \mathrm{~g}$ of yeast extract, $20 \mathrm{~g}$ of dextrose, and 1,000 $\mathrm{mL}$ of distilled water (Maharani et al., 2014). The YM was comprised of $10 \mathrm{~g}$ of glucose, $3 \mathrm{~g}$ of malt extract, $5 \mathrm{~g}$ of peptone, and $5 \mathrm{~g}$ of yeast extract (Kim et al., 2002).

\section{Cultivation of M. pelianthina mushroom (Elfita} et al., 2014)

Mycena pelianthina mycelium was inoculated by transferring 5 plugs, respectively ( $5 \mathrm{~mm}$ diameter) from rejuvenating medium into a $250 \mathrm{~mL}$ Erlenmeyer flask containing $100 \mathrm{~mL}$ of PDYB, MCM, and YM, respectively. Each Erlenmeyer flask was closed with cotton and glued with plastic wrap. The inoculated media were then incubated for $15,20,25,30$ days at room temperature using a rotary incubator.

\section{Weight of M. pelianthina mycelia (Irianto et al., 2008)}

The mycelial cultures that had been incubated for $15,20,25$, or 30 days were filtered using Whatman papers no. 41, and a vacuum pump was used to accelerate the filtration. The mycelia from each filtered sample were weighed and then dried in an oven at a temperature of $60^{\circ} \mathrm{C}$ until a constant weight was obtained and the dry weight was recorded.

\section{Determination of $\mathrm{pH}$ medium}

The $\mathrm{pH}$ of medium was determined using Horiba Laqua pH meter (Wagestu et al., 2016).

Extraction of M. pelianthina mycelium (Vamanu, 2013)

Extraction of $M$. pelianthina mycelium was conducted following the procedures shown in the diagram Figure 1.

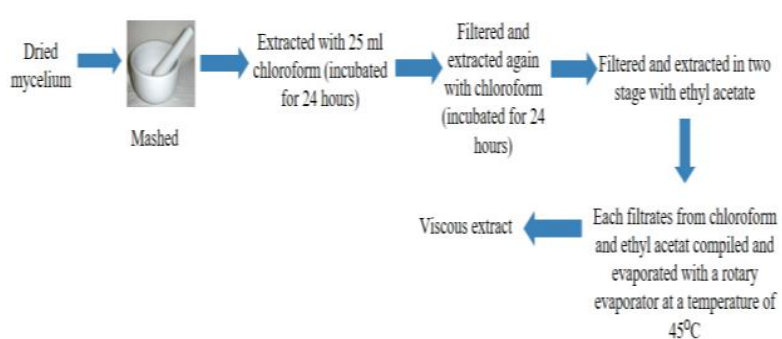

Figure 1. Extraction of M. pelianthina mycelia

\section{Production of $M$. pelianthina filtrate extract (Ekowati et al., 2011)}

Production of $M$. pelianthina filtrate extract was conducted following the procedures shown in the diagram Figure 2.

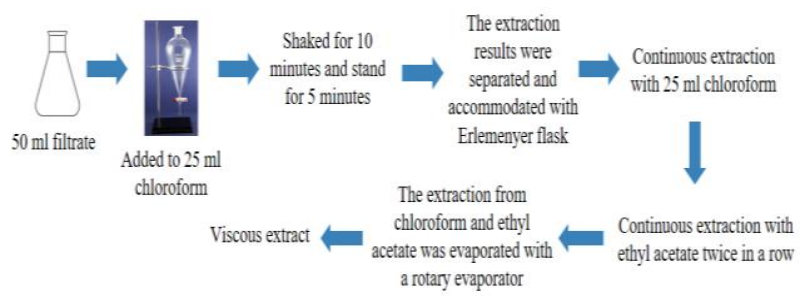

Figure 2. Production of M. pelianthina extract mixtures

\section{Identification of secondary metabolite group compounds (Wagner et al., 1984)}

Identification of alkaloid, terpenoid, and flavonoid were carried out using a silica gel GF254 plate with the mobile phase of dichloromethane: methanol (10:1) mixture. Each eluted spot was calculated by the value of Retardation Factor (Rf) with the following formula.

Rf $(\mathrm{cm})=\frac{\text { Distance moved by the compound }}{\text { Distance moved by the surface of the solvent }}$

\section{Statistical analysis}

Mycelial dry weight data obtained were analyzed using ANOVA at $\mathrm{p}=5 \%$ and were continued with the Duncan's Multiple Range Test (DMRT) at the $p$ 
values. The detection of secondary metabolites was performed descriptively.

\section{RESULTS AND DISCUSSION}

\section{Mycena pelianthina mycelial biomass}

The growth of M. pelianthina mushroom on MCM and YM media continued to increase until 30 days of incubation. The growth of $M$. pelianthina mushroom on PDYB medium increased until 20 days and then decreased during 25 and 30 days (Figure 3). The interaction between the types of media and the incubation time significantly affected the dry weight of mycelia (Table 1).

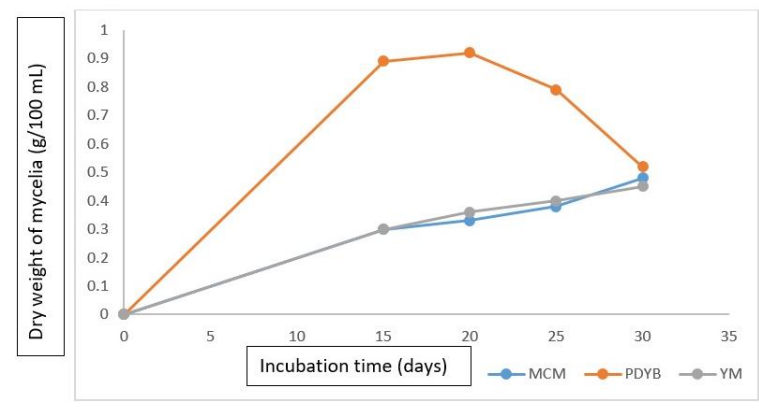

Figure 3. The growth of $M$. pelianthina in mushroom complete medium (MCM), potato dextrose yeast broth (PDYB), and yeast malt extract medium (YM), respectively.

The growths of M. pelianthina on MCM and YM, respectively, were in the exponential phase from 15 to 30 days of incubation. The growth of $M$. pelianthina in the MCM and YM, respectively, were not in either the stationary phase nor the death phase because the mushroom was still utilizing nutrients for growth so that mycelial dry weight continued to increase. The growth of $M$. pelianthina on PDYB medium entered the death phase subsequently, during the 25 to 30 days of incubation. According to Setyati et al. (2015), the death phase was characterized by a decreasing rate of growth caused by a lack of growth material such as vitamins and mineral elements

PDYB was the best medium for the growth of $M$. pelianthina mycelium regarding the production of mycelial dry weight. According to Teoh \& Don (2012), yeast extract, glucose, $\mathrm{MgSO}_{4} .7 \mathrm{H}_{2} \mathrm{O}$, $\mathrm{KH}_{2} \mathrm{PO}_{4}, \mathrm{~K}_{2} \mathrm{HPO}_{4}$ contained in $\mathrm{MCM}$ can increase the mycelial growth. On the other hand, Laurie et al. (2015) reported that potatoes in PDYB medium contain more complete minerals and vitamins. Potatoes contain minerals such as calcium, iron, magnesium, phosphorus, potassium, and zinc as well as vitamins such as thiamine, niacin, riboflavin, and vitamin B6. Based on the research by Behera \& Gupta (2015), YM produced a lower mycelial dry weight compared to MCM for the mushroom Rusula spp, Pleurotus sajor-caju, Lentinus tuberregium and Calocybe indica because YM has limited mineral elements.

Table 1. Statistical analysis of dry weight mycelium of $M$. pelianthina in MCM, PDYB, YM medium and incubation time

\begin{tabular}{ccc}
\hline Media & $\begin{array}{c}\text { Incubation Time } \\
\text { (days) }\end{array}$ & $\begin{array}{c}\text { Dry Weight of Mycelia } \\
(\mathbf{g} / \mathbf{1 0 0} \mathbf{~ m L})\end{array}$ \\
\hline MCM & 15 & $0.30^{\mathrm{a}}$ \\
& 20 & $0.33^{\mathrm{a}}$ \\
& 25 & $0.38^{\mathrm{a}}$ \\
& 30 & $0.48^{\mathrm{a}}$ \\
\hline PDYB & 15 & $0.89^{\mathrm{b}}$ \\
& 20 & $0.92^{\mathrm{b}}$ \\
& 25 & $0.79^{\mathrm{b}}$ \\
YM & 30 & $0.52^{\mathrm{a}}$ \\
& 15 & $0.30^{\mathrm{a}}$ \\
& 20 & $0.36^{\mathrm{a}}$ \\
& 25 & $0.40^{\mathrm{a}}$ \\
Note: Numbers with different notation show significantly
\end{tabular}

Based on the ANOVA results (Table 2), the interaction between the type of medium and the incubation time had a significant effect on the dry weight gain of mycelia. Mycelial growth can be influenced by several factors such as growth medium, incubation time, $\mathrm{pH}$, temperature, nutrition and several environmental factors (Muthu $\&$ Shanmugasundaram, 2015). The growth medium is the most important factor because it contains nutrients needed for mycelial growth. The nutrients needed by microorganisms for growth include carbon, nitrogen, non-metallic elements such as sulfur and phosphorus, metal elements such as $\mathrm{Ca}$, $\mathrm{Zn}, \mathrm{Na}, \mathrm{K}, \mathrm{Cu}, \mathrm{Mn}, \mathrm{Mg}$, and $\mathrm{Fe}$, vitamins, water, 
and energy. Mushrooms require a certain amount of time to break the sources of nutrients down that are available in the medium and then use it up for growing and production of secondary metabolites (Cappucino \& Sherman, 2014).

PDYB is the main medium for mushrooms growth. Mushrooms can metabolize starch in potatoes resulting in dissolved sugars that act as sources of carbon and energy as well (Laurie et al., 2015). Potato is a complex medium that provides nitrogen, enzymes, vitamins and mineral elements for mushrooms growth. In addition, the yeast extract in the PDYB contained not only organic nitrogen; but also vitamins, minerals, sugar and cofactors. High carbon sources and yeast contain various supporting compounds for growth, enabling efficient mushroom growth (Suciatmih, 2010).

Every type of mushroom required a different suitable medium to grow optimally (Smith \& Onions, 1994). Each medium has different nutrient compositions to support the mushroom's needs for growing, but the essential goal is to provide balanced nutrients and at adequate concentrations that can enable the mushroom growing well.

Table 2. Anova of dry weight of M.pelianthina mycelia in different growth media and incubation times

\begin{tabular}{cccccc}
\hline $\begin{array}{c}\text { Source of } \\
\text { Variation }\end{array}$ & $\begin{array}{c}\text { Degrees of } \\
\text { Freedom }\end{array}$ & $\begin{array}{c}\text { Sum of } \\
\text { Squares }\end{array}$ & $\begin{array}{c}\text { Mean } \\
\text { Square }\end{array}$ & F & Sig \\
\hline Treatment & 11 & $1.703(\mathrm{a})$ & 0.155 & 10.314 & 0.000 \\
Time & 3 & 0.017 & 0.006 & 0.380 & 0.768 \\
Medium & 2 & 1.318 & 0.659 & 43.910 & 0.000 \\
Time $\times$ Medium & 6 & 0.368 & 0.061 & 4.083 & 0.006 \\
Error & 24 & 0.360 & 0.015 & & \\
\hline Total & 35 & 2.063 & & &
\end{tabular}

Note : Sig value $<0.05$ indicates that the factorial variables have a significant effect on dry weight gain of mycelia

Based on the results of the study, mushrooms grown on MCM decreased the $\mathrm{pH}$ (Table 3). According to Angelia et al. (2013), the increase of incubation time lowered the medium $\mathrm{pH}$ since more sugars were converted into acids. The organic acids produced by the fungus included pyruvic acid and citric acid. The PDYB and YM, respectively, showed $\mathrm{pH}$ increase due to mushroom growth (Table 3). According to Sari (2011), the increased $\mathrm{pH}$ was caused by the production of ammonia from nitrogen containing compounds in the growth medium.

Table 3. $\mathrm{pH}$ Values of the growth media before and after incubation periods

\begin{tabular}{cccc}
\hline \multirow{2}{*}{ Medium } & Incubation & \multicolumn{3}{c}{ Average } \\
\cline { 3 - 4 } MCM & Time (days) & Initial $\mathbf{~ H H}$ & Final pH \\
& 15 & 6 & 5 \\
& 20 & 6 & 5 \\
& 25 & 6 & 5 \\
\hline PDYB & 30 & 6 & 5 \\
& 15 & 6 & 7 \\
& 20 & 6 & 7 \\
YM & 25 & 6 & 7 \\
& 30 & 6 & 6 \\
& 15 & 6 & 7 \\
& 20 & 6 & 7 \\
& 25 & 6 & 7 \\
\hline
\end{tabular}




\section{Identification of secondary metabolite group}

To elucidate the class of secondary metabolites the mycelial extracts of $M$. pelianthina obtained from chloroform and ethyl acetate, respectively, were then mixed and tentatively determined through
TLC method. The results of the active compounds characterized in $M$. pelianthina mycelial concentrated extracts are presented in Figure 4. Alkaloid, terpenoid and flavonoid groups were detected in each medium and the distribution was different for each extract.

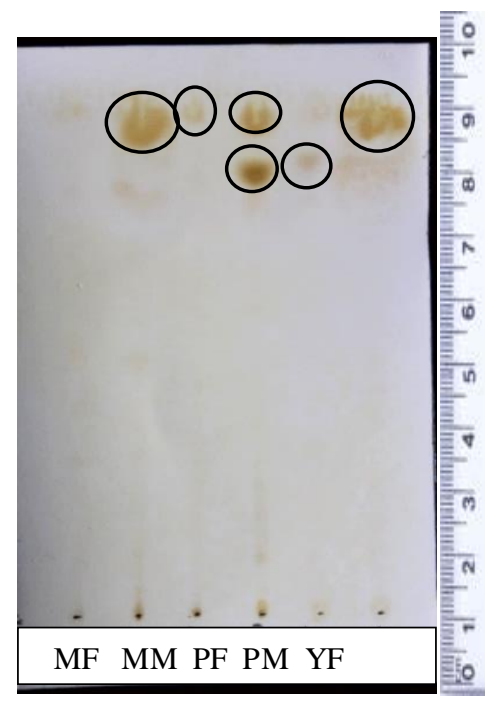

A

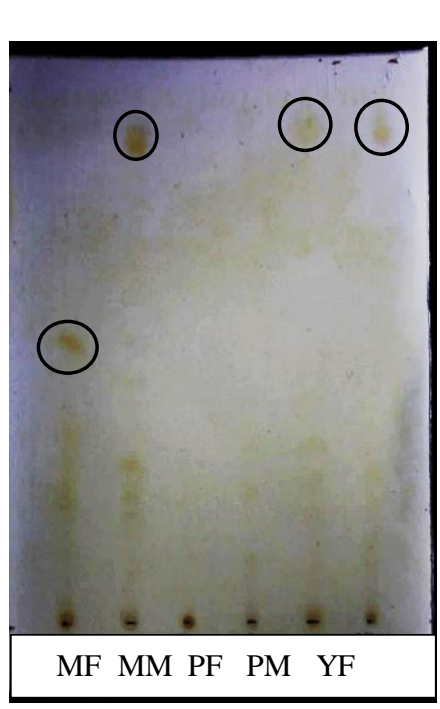

$\mathrm{D}$

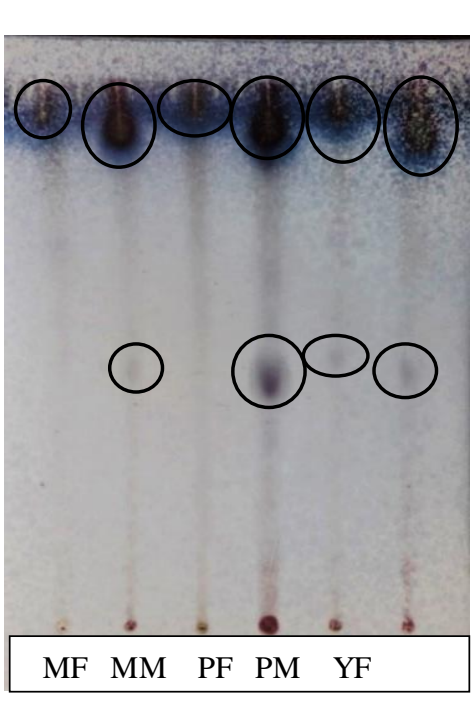

B

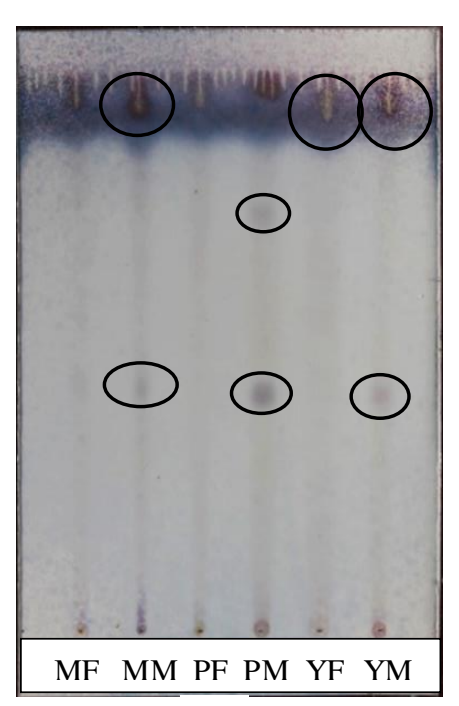

$\mathrm{E}$

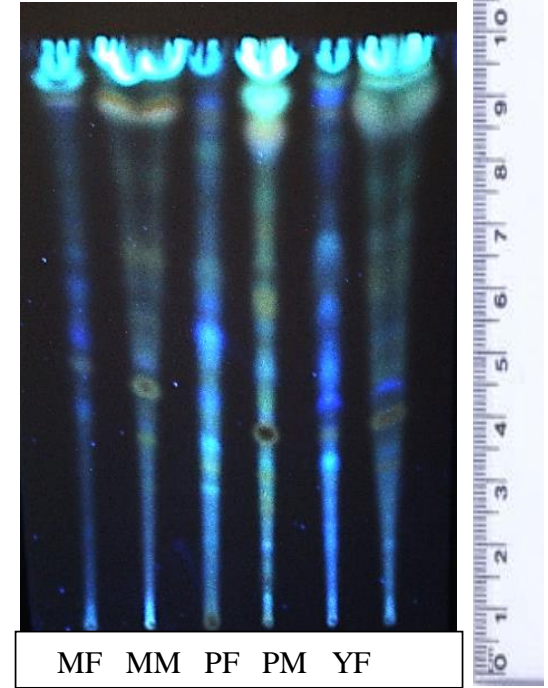

$\mathrm{C}$
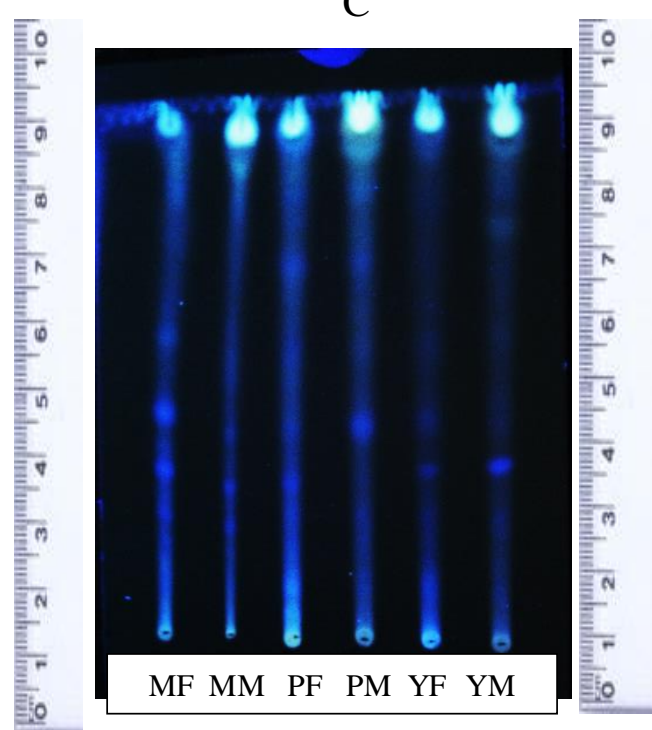

$\mathrm{F}$

Figure 4. Chloroform extract chromatogram: (A) alkaloid, (B) terpenoid, and (C) flavonoid; ethyl acetate extract chromatogram: (D) alkaloid (E) terpenoid (F) flavonoid

Brownish-yellow spots were formed on the GF254 silica gel plate after being sprayed with Dragendorff reagents (Figure 4.A and 4.D). The Rf values ranged from 0.81 to 0.92 in chloroform elucidation and 0.51 to 0.91 in ethyl acetate eluent. Furthermore, blackish purple spots were formed on the GF254 silica gel plate after sprayed with Vanillin-sulfuric acid reagent (Figure 4.B and 4.E). The Rf values ranged from 0.44 to 0.92 in chloroform mobile phase and 0.41 to 0.91 in ethyl acetate elution. On the other hand, Figures 4.C and 4.F show blue and green spots after sprayed with 
$\mathrm{AlCl}_{3}$ reagents observed under $366 \mathrm{~nm}$ UV light. The $\mathrm{Rf}$ values ranged from 0.12-0.95 when elucidated using chloroform and 0.20-0.94 for ethyl acetate.

The production of bioactive metabolites from microorganisms depends on special adaptations to the environment (Padmavathi et al., 2012). The growth medium and incubation conditions play an important role in the production of secondary metabolites. Each observed medium had different compositions. MCM contains the main carbon source of glucose which is more easily metabolized by mushroom. Micronutrients $\mathrm{KH}_{2} \mathrm{PO}_{4}, \mathrm{~K}_{2} \mathrm{HPO}_{4}$, $\mathrm{Na}_{2} \mathrm{HPO}_{4} .12 \mathrm{H}_{2} \mathrm{O}, \mathrm{MgSO}_{4} .7 \mathrm{H}_{2} \mathrm{O},\left(\mathrm{NH}_{4}\right)_{2} \mathrm{SO}_{4}$ and $\mathrm{KCl}$ are important elements for the production of secondary metabolites (Teoh \& Don, 2012). PDYB contains a complex carbon source derived from potatoes. YM also contains complex carbon sources derived from maltose. Alkaloids, terpenoids, and flavonoids were detected in PDYB and YM. This was not in accordance with the statement Purwantini et al. (2015), that complex carbon sources such as malt extract are more difficult to be metabolized by microorganisms and can result in inhibition of biosynthesis of secondary metabolites. Ramakhrisna \& Ravishankar (2011) reported that the production of secondary metabolites as self-defense will increase under stress.

Figure 4 shows trends in accordance with the statement of Suhaenah \& Nuryanti (2017), the potential results of the presence of alkaloids are marked with yellow to orange spots after being sprayed with Dragendorff reagent. According to Eva (2007), Rf values for alkaloids ranged from 0.69 to 0.9. Saxena et al. (2013) stated that alkaloids have many pharmacological activities including anti-hypertensive, anti-arrhythmic, antimalaria, and anti-cancer effects.

Vanillin-sulfuric acid reagent is used to detect terpenoid compounds, steroids and essential oil components (Sulistijowati \& Gunawan, 2001). Terpenoid compounds on the TLC will change to blue-purple colored spots after sprayed with vanillin-sulfuric acid reagent. Terpenoids are bioactive compounds that can be used as antifungal compounds (Lutfiyanti et al., 2012). The toxic nature of terpenoids is known to have the ability to inhibit fungal growth by damaging cell membranes.

Rahayu et al. (2015) reported, in similar elution system, spots with Rf values between 0.2-0.75 indicate spots containing flavonoids. On the other hand, Firdiyani et al. (2015) stated that flavonoid compounds are non-polar compounds. Flavonoids however have a sugar group which makes it dissolve easily in either polar or semi-polar solvent. According to Prameswari \& Widjanarko (2014), flavonoids are polyphenol compounds which have various pharmacological activities such as antioxidants, anti-inflammatory, and anticancer. Overall, type of medium, incubation time and their interactions process are the key factors in increasing mycelia dry weights simultaneously extraction amplified the secondary metabolites' existences.

\section{CONCLUSION}

Potato dextrose yeast broth was the best medium for the growth of Mycena pelianthina. The highest production of biomass mycelium was $0.92 \mathrm{~g} / 100$ $\mathrm{mL}$ of the media for 20 days of incubation at room temperature. The extract of Mycena pelianthina mycelia contained secondary metabolite compound groups of alkaloid, terpenoid, and flavonoid.

\section{ACKNOWLEDGEMENT}

The author would like to thank Ministry of Research, Technology and Higher Education through Research and Community Service Institute, Jenderal Soedirman University which funded the National Institute of Strategic Research in 2018.

\section{REFERENCES}

Alen, Y., Agresa, F.L. and Yuliandra, Y. 2017. Analisis kromatografi lapis tipis (KLT) dan aktivitas anti hiperurisemia ekstrak rebung Schizostachyum brachycladum Kurz (Kurz) pada mencit putih jantan. Jurnal Sains Farmasi \& Klinis, 3(2), pp. 146-152.

Angelia, M., Periadnadi. dan Nurmiati. 2013. Pengaruh lama pelapukan medium limbah 
industri teh terhadap pertumbuhan miselium produksi jamur kuping hitam (Auricularia polytrica (Mont.) Sacc.). Jurnal Biologi Universitas Andalas, 2(4), pp. 269-276.

Bäurle, J. and Anke, T. 1980. Planta medica, 39, pp. 195-196.

Bäurle, J., Anke, T., Jente, R. and Bosold, F. 1982. Antibiotics from basidiomycetes XVI. Antimicrobial and cytotoxic polyines from Mycena viridimarginata Karst. Arch Microbiology, 132, pp. 194-196.

Behera, S. and Gupta, N. 2015. Utilization of vegetable waste for biomass production of some wild edible mushroom cultures. Tropical Plant Research, 2(1), pp. 5-9.

Cappucino, J.G. dan Sherman N. 2014. Manual laboratorium biologi. Jakarta: EGC.

Ekowati, N., Kasiamdari, R.S., Pusposendjojo, N. and Soegihardjo, C.J. 2011. Daya antimikroba metabolit bioaktif jamur shiitake (Lentinula edodes (Berk.) Pegler) yang dikultur pada tiga jenis medium fermentasi. Majalah Obat Tradisional, 16(3), pp. 133-138.

Ekowati, N., Ratnaningtyas, N.I. dan Mumpuni, A. 2016. Potensi jamur Trametes versicolor dan Russula sp. dalam menghasilkan $\beta$-Glukan melalui proses fermentasi. Prosiding Seminar Nasional Pendidikan Biologi dan Saintek. Universitas Muhammadiyah Surakarta.

Elfita, M., Muharni, dan Sri, W. 2014. Isolasi senyawa metabolit sekunder turunan ftalat dari jamur endofitik tumbuhan brotowali (Tinospora crispa L). Prosiding Seminar Nasional Biodiversitas. 3(2), pp. 241-244. ISBN 2337-506X

Engler, M., Anke, T., \& Sterner, O. 1998. Phytochemistry, 49, pp. 2591-2593.

Eva, M. 2007. Analisis senyawa metabolit sekunder dari batang Stapholobus ferrugineus (Zoll \& Motrizi) Benth yang berfungsi sebagai antioksidan. Jurnal Penelitian MIPA, 1(1), pp. 23-29.
Firdiyani, F., Agustini, T.W. dan Ma'ruf, W.F. 2015. Ekstraksi senyawa bioaktif sebagai antioksidan alami Spirulina platensis segar dengan pelarut yang berbeda. JPHPI, 18(1), pp. 28-37.

Irianto, Y., Susilowati, A. dan Wiryanto. 2008. Pertumbuhan, kandungan protein, dan sianida jamur kuping (Auricularia polytricha) pada medium tumbuh serbuk gergaji dan ampas tapioka dengan penambahan pupuk urea. Bioteknologi, 5(2), pp. 43-50.

Khatua, S., Paul, S. \& Acharya, K. 2013. Mushroom as the potential source of new generation of antioxidant: a review. Research J. Pharm. and Tech. 6(5), pp. 496-505.

Kim, S.W., H.J. Hwang, J.P. Park, Y.J. Cho, C.H. Song, J.W., \& Yun. 2002. Mycelial growth and exo-biopolymer production by submerged culture of various edible mushrooms under different medium. Letters in Applied Microbiology, 34, pp. 56-61.

Laurie, S., Faber, M., Adebola, P., \& Belete, A. 2015. Biofortification of sweet potato for food and nutrition security in south africa. Food Research International, 76, pp. 962-970.

Lutfiyanti, R., Farid, W., \& Dewi, E.N. 2012. Aktivitas antijamur senyawa bioaktif ekstrak geledium latifolium terhadap Candida albicans. Jurnal Pengelolaan dan Bioteknologi, 1, pp. 45-47.

Maharani, M.M., Ratnaningtyas, N.I., \& Priyanto, S. 2014. Penggunaan beberapa medium semisintetik untuk produksi miselium jamur maitake (Grifola frondosa (Dickson: Fr.) S. F. Gray) Isolat Cianjur dan Ekstraksi Kasarnya. Scripta Biologica. 1(1), pp. 20-21.

Muthu, N. and Shanmugasundaram, K. 2015. Effect of five different culture medium on mycelial growth of Agrocybe aegerita, 6(12), pp. 5193-5197.

Padmavathi, T., Nandy, V., \& Agarwal, P. 2012. Optimization of the medium for the production of cellulases by Aspergillus terreus 
and Mucor plumbeus. European Journal of Experimental Biology, 2, pp. 1161-70.

Prameswari, O.M. dan Widjanarko, S.B. 2014. Uji efek ekstrak air daun pandan wangi terhadap penurunan kadar glukosa darah dan histopatologi tikus diabetes mellitus. Jurnal Pangan dan Agroindustri, 2(2), pp. 16-27.

Purwantini, I., Wahyono, Mustofa, dan Susidarti, R.A. 2015. Pengaruh medium pada pertumbuhan fungi endofit Ip-2 dan produksi metabolit aktif inhibitor polimerisasi Hem. Traditional Medicine Journal, 20(1), pp. 5156.

Rahayu, S., Kurniasih, N., \& Amalia, V. 2015. Ekstraksi dan identifikasi senyawa flavonoid dari limbah kulit bawang merah sebagai antioksidan alami. Al Kimiya, 2(1), pp. 1-8.

Ramakrishna, A. and Ravishankar, G.A. 2011. Influence of abiotic stresss signals on secondary metabolites in plants. Plant Signal Behaviour, 6(11), pp. 1720-31.

Ren, L., Hemar, Y., Perera, C.O., Lewis, G., Krissansen, G.W. and Buchanan, P.K. 2014. Antibacterial and antioxidant activities of aqueous extracts of eight edible mushrooms. Bioactive Carbohydrate Dietary Fibre 3, pp. 41-51.

Saputra, N.W. 2010. Aktivitas antitumor polisakarida ekstraseluler ganoderma lucidum indigenous dengan masa inkubasi yang berbeda pada ganoderma medium complex. Skripsi. Purwokerto: Fakultas Biologi Universitas Jenderal Soedirman.

Sari, M.P. 2011. Pemanfaatan kompos jerami padi dan sampah pasar sebagai soil conditioner. Skripsi. Bogor. Institut Pertanian Bogor.

Saxena, M., Saxena, J., Singh, D. and Gupta, A. 2013. Phytochemistry of medicinal plants. Journal of Pharmacognosy and Phytochemistry, 1(6).

Setyati, W.A., Martani, E., Triyanto, Subagiyo, dan Zainuddin, M. 2015. Kinetika pertumbuhan dan aktivitas protease isolat 36k dari Sedimen Ekosistem Mangrove, Karimunjawa, Jepara. Ilmu Kelautan, 20(3), pp. 163-169.

Smith, D., \& Onions, A.H.S. 1994. The preservation and maintenance of living fungi, 2nd edition. International Mycological Institute, CAB International. pp. 15-28.

Suciatmih. 2010. Pengaruh konsentrasi antimikroorganisme, medium fermentasi, dan waktu inkubasi terhadap pertumbuhan Absidia Corymbifera (Cohn) Sacc. \& Trotter dari Jamur Endofit Fusarium Nivale (Fr.) Ces. Medium Litbang Kesehatan, 20, pp.17-24.

Suhaenah, S. dan Nuryanti, S. 2017. Skrining fitokimia ekstrak jamur kancing (Agaricus bisporus). Jurnal Fitofarmaka Indonesia, 4(1), pp. 199-200.

Sulistijowati, A., \& Gunawan, D. 2001. Efek ekstrak daun kembang bulan (Tithonia diversifolia) terhadap Candida albicans serta Profil Kromatografinya. Cermin Dunia Kedokteran, 130, pp. 32-36.

Teoh, Y.P. and Don, M.M. 2012. Nutrient improvement using statistical optimization for growth of Schizophyllum Commune, and its antifungal activity against wood degrading fungi of rubberwood. Biotechnology.Progress, 28(1), pp. 232-241.

Vamanu, E. 2013. Studies on the antioxidant and antimicrobial activities of Pleurotus ostreatus PSI101109 mycelium. Pakistan Journal of Botany, 45(1), pp. 311-317.

Wagestu, I.W.A., Antara, N.S. dan Putra, G.G.P. 2016. Pengaruh $\mathrm{pH}$ awal media dan lama fermentasi terhadap produksi kalsium sitrat dari limbah brem dengan menggunakan Aspergillus niger ATCC 16404. Jurnal Rekayasa dan Manajemen Agroindustri, 4(4), pp. 70-79.

Wagner, H., Bladt, S. and Zgainski, E.M. 1984. Plant drug analysis, $a$ thin layer chromatography atlas. 2nd edition. Berlin heidelberg: Springer. 